\title{
Die Lukaanse Jesusbeeld: In dialoog met Wilhelm Bousset se 'Kyrios Christos'
}

\author{
Sanrie van Zyl \& Andries van Aarde \\ Departement Nuwe-Testamentiese Wetenskap (Afd A)
}

Universiteit van Pretoria

\begin{abstract}
The Lucan image of Jesus: In dialogue with Wilhelm Bousset's 'Kyrios Christos'

Wilhelm Bousset poses in his epoch-making work 'Kyrios Christos: Geschichte des Christusglaubens von den Anfaingen des Christentums bis Irenaeus' the question of the context and reference of the title 'Kyrios Christos'. He concludes that this title reflects the Luke-Acts image of Jesus, originating from a pagan Hellenistic background. This paper follows the argument of Bousset concerning the titles 'Christos' and 'Kyrios' and examines corrections given on his views. From this evaluation the conclusion is drawn that the Christology of Luke-Acts should be viewed as originating in the Antiochian Christian community, and thus against a Israelite-Hellenistic background. Jesus is represented as the risen Lord, the Messiah ruling his church. However, this conclusion doesn't account for Luke-Acts as a narrative, nor does it reflect an intensive study of the social and cultural world of the text. Therefore the possibilities of using a social-scientific as well a narratological approach in dealing with the title 'Kyrios Christos' will be explored.
\end{abstract}

\section{INLEIDING}

\subsection{Probleemstelling}

In 1913 het Wilhelm Bousset sy epogmakende werk Kyrios Christos: Geschichte des Christusglaubens von den Anfängen des Christentums bis Irenaeus gepubliseer. As eksponent van die Religionsgeschichtliche Schule toon hy aan dat die Christelike geloof binne die konteks van kontemporêre godsdienste, soos die Joodse en Hellenistiese, ontwikkel het. Hy stel hom ten doel om hierdie konteks van die vroeë kerk te rekonstrueer. Sy analise konsentreer op die beskrywing van die funksie van Christologiese

* Hierdie artikel is gebaseer op 'n skripsie wat ingedien en aanvaar is as deel van die vereistes vir die BD-graad (1996), Departement Nuwe-Testamentiese Wetenskap, Fakulteit Teologie (Afd A), Universiteit van Pretoria, onder leiding van prof dr A G van Aarde. 
titels en die klassifikasie van hierdie titels teen 'n bepaalde agtergrond wat onderskeidelik skerp van mekaar onderskei moet word. In sy Kyrios Christos toon hy aan dat die apokaliptiese Joodse Christendom se gebruik van die titel 'Seun van die mens' 'n eie besondere refleksie is op Jesus, terwyl die Hellenistiese Christendom voorkeur gegee het aan die kultiese 'Kurios'-Christologie. Volgens Bousset (1913:76-77) gee die Lukaanse korpus die volledigste prentjie van die heidens-Hellenistiese gemeente se Jesusbeeld. Meer toegespits gesê: die 'Kurios Christos'-titel beskryf die Lukaanse Jesusbeeld in 'n neutedop.

Bousset is in latere navorsing skerp gekritiseer vir sy siening dat die vroeë Christendom vớr Paulus so skerp in twee afsonderlike ontwikkelings geklassifiseer kan word (vgl bv Conzelmann 1969:1-10; Hahn 1974:112-126; Hengel 1986:100-104; Schmithals 1994:86-90). Sy siening van die vroeë vorm van Christologie as 'n apokaliptiese 'Seun van die mens'-Christologie is skerp bevraagteken en sy siening dat die 'Kurios'-titel 'n Christologie reflekteer wat slegs in 'n nie-Palestynse agtergrond (gedomineer deur die invloed van heidense kultusse en keiserkultus) gefunksioneer het, is verwerp. Met hierdie kritiek het 'n belangrike insig van hom egter in die slag gebly en geniet dit ongelukkig nie meer die aandag wat dit verdien nie. Dit is naamlik dat die 'Kurios Christos'-titel die Jesusbeeld van die Lukaanse korpus weerspieël. Hierdie insig behoort selfs sy skerpste kritici hom ter ere na te gee (vgl o a O'Neill 1961:116145; Hahn 1974:112-125; Hanson 1974:69; De Jonge 1976:106-107; Hengel 1986: 103; Joubert 1991:144; Ladd 1993:374-378).

\subsection{Doelstelling}

Die doelstelling van hierdie studie is om in te gaan op die problematiek wat Bousset se insig oproep, naamlik dat die 'Kurios Christos'-titel die Lukaanse Jesusbeeld reflekteer. Verder word daar in hierdie studie moontlike benaderings uitgespel wat riglyne aan die navorser kan bied om die geidentifiseerde problematiek op sinvolle wyse te hanteer. Vir die Bybelwetenskap, en veral vir die Christelike geloofsgemeenskap, is dit belangrik om te weet wat die vroeë kerk se siening van Jesus was. Hoe het die vroeë Christene hulle verhouding met die Verlosser verstaan? Meeks (1988:10) stel dit só:

All the more, the meaning of a person's life is to be found not by abstraction from the historical situation but by understanding the person's interaction with that situation and the engagement of those who follow after with the memory and effects of that prior transaction. Personal meaning transcends the particular not by stripping it away but by deeply engaging it in a dialogue that unfolds toward the future. 
Bousset se opmerking oor die Lukaanse Jesusbeeld in 'n neutedop, bring myns insiens die navorser voor twee probleme te staan, naamlik:

* Wat is die bepaalde agtergrond waarteen die titel 'Kurios Christos' tot stand gekom het?

* Waarop sou hierdie titel inhoudelik betrekking hê, gesien die konteks waarbinne dit gefunksioneer het?

\subsection{Werkwyse}

Ten einde die omvang van die problematiek te illustreer, word Bousset se hantering van die titels 'Christos' (hoofstuk 1) en 'Kurios' (hoofstuk 3) hanteer, soos in sy boek Kyrios Christos (1913) uiteengesit. Hierna volg 'n kort uiteensetting van die kritiek op sy siening, veral dié deur Hengel (1981), Rawlinson (1926) en Crossan (1992). Hierdie drie navorsers bring korreksies op Bousset se standpunte ten opsigte van die agtergrond van die vroeë kerk, sowel as ten opsigte van die inhoudelike betekenis van die titels 'Seun van die mens' en 'Kurios'. Hengel en Rawlinson reageer eksplisiet op Bousset, en Crossan implisiet. Bultmann en Schmithals verfyn Bousset se weergawe van die ontwikkeling van die vroeë Christelike kerk as onderskeibaar in twee fases, naamlik die Joods-Palestynse en die Hellenisties-heidense. Dié insigte word kortliks verduidelik.

Ferdinand Hahn bou op 'n alternatiewe wyse voort op die siening van Bousset. Hy kom met nuwe insigte vorendag, veral met betrekking tot die benaming 'Kurios Christos', deurdat hy dit in kombinasie behandel. Hahn se hantering van die probleem sal ook onder oë geneem word. Hierop volg 'n kort samevatting van elk van die gemelde geleerdes se sienings. Die tekortkomings in hulle insigte met betrekking tot die hantering van enersyds die probleem van die konteks en andersyds in verband met die inhoudelike referensie van die titel 'Kurios Christos' in die Lukaanse korpus, word uitgewys.

Moderne navorsing op die gebied van die Christologie eis deesdae dat vorige sienings van Christologiese titels weer eens aan ondersoek onderwerp word, maar ook dat die Nuwe-Testamentiese Christologie méér sal wees as net die histories-kritiese studie van titels waarvan die fondament deur Bousset gelê is (vgl Hurtado 1979:23; Kee 1984: 189-191; Duling 1984:193-199; Malina \& Neyrey 1988:x-xvii; Van Aarde 1994:4453). Die klem val eerder op ' $n$ holistiese benadering waarin die ondersoek na titels wel 'n funksie het, maar ondersoek word met inagneming van sowel die eie literêre aard van die betrokke korpus waarin dit voorkom as die sosiale konteks waarbinne dit ge- 
funksioneer het. Die moontlikhede wat die sosiaal-wetenskaplike en narratologiese benaderings onderskeidelik kan bied vir die beskrywing en verduideliking van die Jesusbeeld in die Lukaanse korpus, word aangestip.

In die slot van die studie word die onderhawige probleem met betrekking tot die hantering van die Jesusbeeld in die Lukaanse korpus weer eens kortliks saamvat.

\section{BOUSSET SE KYRIOS CHRISTOS: BAANBREKERSWERK IN DIE CHRIS- TOLOGIE}

\subsection{Jesus: 'Seun van die mens' in die Palestynse gemeente}

Bousset (1913:1-22) het hom daarvan weerhou om 'n gedetailleerde uiteensetting te gee van Jesus se siening van Homself as 'Christus', in die sin van Jesus se sogenaamde selfbewussyn. In sy hantering van die Christologie van die 'oergemeente' laat hy homself egter kortliks hieroor uit.

By die eerste gemeente in Jerusalem het daar geen twyfel bestaan dat Jesus van Nasaret vir sekere Israeliete die verwagte Messias was nie. Die tradisies grondliggend aan die Sinoptiese Evangelies as narratiewe gebruik geen titel vir Jesus nie, maar slegs die eienaam ó 'Inoov̂s. Daar word nêrens verwys na 'Christus', 'die Seun van Dawid', 'die Seun van God' of die 'Seun van die mens' as titels nie, maar slegs na 'Jesus'. Tog, in die 'Seun van die mens'-uitsprake (ó viòs tov̂ $\dot{\alpha} \nu \theta \rho \omega \dot{\omega} \pi o v$ ) wat in die mond van Jesus self voorkom, vind ons volgens Bousset (1913:5) die totaliteit van die Christologie van die 'oergemeente'. Hy verwys daarna as die vertrekpunt vir die ondersoek na die teologie van Palestynse gemeente. Hierdie uitsprake moet dus nie verstaan word as selfbeskrywing van Jesus nie, maar as die eerste belydenisformule van die Christelike kerk.

Teen watter agtergrond het hierdie titel ontstaan? Volgens Bousset (1913:12) moet dit verstaan word teen die agtergrond van die apokaliptiese geskrif Daniël (7:13). Hiér word die verwysing 'seun van die mens' nie gebruik as titel nie, maar as die Aramese idioom vir die mens in generiese sin (vgl Ps 8:4). In latere literatuur soos die Ethiopiese. Henogboek (48:10; 52:4) is die 'Seun van die mens'-figuur geïnterpreteer as 'n hemelse figuur wat verlossing vir die mensdom sal bring, met ander woorde 'n Messias-figuur. In die apokriewe geskrif IV Esra $(13: 3,12)$ word 'n hemelse figuur 'soortgelyk aan die figuur van 'n mens' as Messias beskryf. Op soortgelyke wyse is die titel 'Seun van die Mens' volgens Bousset (1913:16) in die evangelies gebruik as

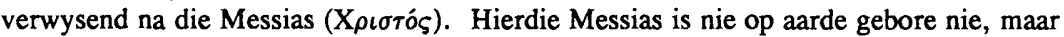
is preëksistent - 'sy naam is genoem nog voor die son en aarde geskep is'. Hierdie 
figuur sou egter in die toekoms op die wolke verskyn om 'n belangrike rol te speel in die groot wêreldgerig van God waar die wêreld katastrofies tot 'n einde sal kom dooies sal opstaan om geoordeel te word, sommiges om die ewige lewe te beërwe en ander om die ewige dood in te gaan. Jesus van Nasaret is in verband gebring met hierdie Messias. Met die dood van Jesus is die hoop op ' $n$ aardse 'Seun van Dawid' wat die koninkryk van Dawid weer sou oprig, vernietig, maar gou is hierdie teleurstelling vervang met die belydenis dat Jesus as 'Seun van die Mens' aan die regterhand van God sit en weer op die wolke sal terugkeer om die heil na die aarde toe te bring (Bousset 1913:17). Só word die eerste martelaar Stefanus se visie op Jesus in Hand 7:56

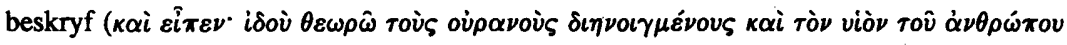

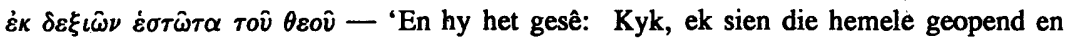
die Seun van die mens aan die regterhand van God staan').

Dat die titel 'Seun van die mens' hier in Handelinge voorkom (en op soortgelyke wyse ook in Luk 22:69), sien Bousset as aanduiding van die getroue wyse waarop die Lukaanse korpus die Christologie van die Palestynse gemeente weerspieël. Die belydenis dat Jesus die 'Seun van die mens' is, is die Shibboleth wat die kring van Jesusdissipels van die Joodse sinagoge geskei het, maar het terselfdertyd ook die kern van die nuwe geloof van die eerste Christelike gemeenskap gevorm.

\subsection{Jesus: Die 'Kurios' van die heidens-Christelike gemeente}

\subsubsection{Inleidende opmerkings}

Bousset (1913:75) lei die derde hoofstuk van sy boek Kyrios Christos: Geschichte des Christusglaubens von den Anfängen des Christentums bis Irenaeus soos volg in: 'Zwischen Paulus und der palästinischen Urgemeinde stehen die hellenistischen Gemeinden in Antiochien, Damaskus, Tarsus.'

Volgens Bousset (1913:76-77) het Paulus sy ontwikkeling as Christen op Hellenistiese bodem beleef. Die evangelie wat Paulus verkondig (soos dit byvoorbeeld in I Kor 15:1 gestel word), het in die heidens-Christelike gemeente van hoofsaaklik Antiochië ontstaan. Die vraag wat gevolglik opkom, is: wat is die siening van die heidens-Christelike gemeente met betrekking tot Jesus? Bousset (1913:76-77) stel dat die Lukaanse korpus die volledigste antwoord op hierdie vraagstuk bied.

\subsubsection{Die 'Kurios'-titel as beskrywing vir die heidens-Hellenistiese Jesusbeeld}

In die heidens-Christelike gemeente het die benaming Xoırós wat in die Palenstynse gemeente só 'n deurslaggewende rol gespeel het, die status as titel verloor en word dit

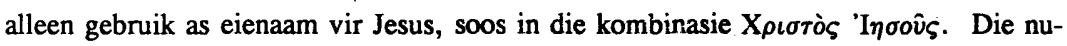


we titel wat gebruik is om na Jesus te verwys, is ó kìpıos. In hierdie opsig onderskei Bousset duidelik tussen die vokatief $\kappa \grave{p} \iota \varepsilon$ wat algemeen in die Nuwe Testament voorkom en die volle titel $\dot{o}$ kì aangetref word. Die vokatief кì $\iota \varepsilon$ is in die Nuwe Testament in wye omvang as aanspreekvorm vir onder andere God, Christus en hemelse wesens gebruik, maar gee ook uitdrukking aan die onderdanigheid van 'n slaaf teenoor sy/haar heer en 'n seun teenoor sy vader, en is gebruik as aanspreekvorm vir 'n geëerde persoon.

Waar die benaming ó kì van Matteus, Markus (uitgesonder die onegte Markusslot, Mark 16:19) en Johannes, as hoogheidstitel gebruik word nie, is dit wel die geval in die Lukasevangelie. In Lukas

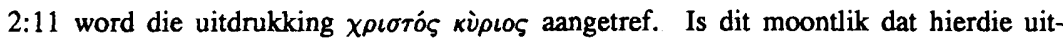
drukking 'n Aramese oorsprong kan hê en as bewys sou kon dien dat dit as titel in die Palestynse gemeente gefunksioneer het? Bousset se hele argument sou hiermee die nekslag toegedien word. Die voorkoms van hierdie kombinasie word egter deur Bousset (1913:79) verklaar as 'n onkorrekte vertaling van die Ou-Testamentiese formule 'die gesalfde van die Here', oorgeneem vanuit die Septuaginta (LXX). Die Septuaginta vertaal byvoorbeeld Klaagl 4:20 ('die asem van ons neus, die gesalfde van die Here') as

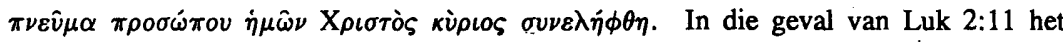
Lukas as redaktor egter self die kì die wyse die eerste tree in die rigting van die gebruik kìpıoৎ as titel vir Christus op heidens-Hellenistiese bodem.

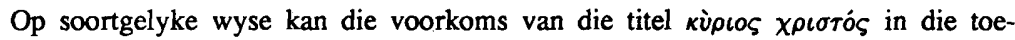
sprake van Petrus, tradisioneel gesien as komende vanuit die Palestynse gemeente, verklaar word. Lukas het as redaktor hierdie titel (vgl Hand 2:36) in die mond van Petrus gelê. Teenoor die apokaliptiese 'Seun van die Mens' wat in die toekoms op die wolke sal verskyn, staan die teenwoordige Heer van die gemeente 'Kurios Christos'.

\subsection{3 'Kurios Christos': Die teenwoordige Heer van die gemeente}

Op heidens-Hellenistiese bodem gaan dit nie alleenlik oor 'n nuwe titel wat aan Jesus gekoppel is nie, maar ook om 'n nuwe saak - die titel кì nuwe, unieke verhouding wat daar bestaan tussen die Heer en sy gemeente. Eie aan die aard van die heer-slaaf verhouding is die gemeente die eiendom van hulle Heer. Dit gaan ook nie om die persoonlike verhouding van die enkeling met die verhoogde Christus nie, maar om die gemeente as korporatiewe liggaam wat in hulle diens aan God die

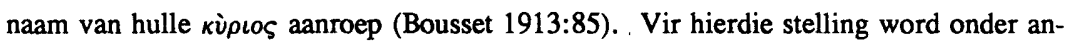

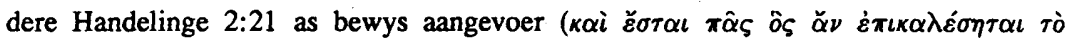

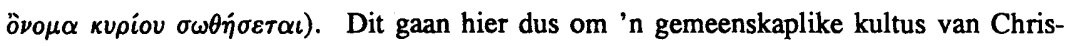


tene. Elke Christen word in die Christuskultus ingelyf deurdat die naam van Christus as кì die doop betree die Christen die godsdienstige lewe van die Christelike geloofsgemeenskap en mag dan aan die heilige maaltyd deelneem. Jesus as kù heid as gasheer op - die gemeente versamel rondom Christus as die 'kultusheld' net soos die aanhangers van die Egiptiese god Serapis rondom die tafel van hulle kultusheld versamel het (Bousset 1913:86).

By geleentheid van die heilige maal speel die kultusgebed 'n belangrike rol. Volgens Bousset is die gebed aanvanklik tot God in die naam van Jesus Christus gerig. Later word dit direk aan Christus as kì Maranatha (I Kor 16:22) aantoon. Volgens Bousset (1913:82-4) kan die absolute ge-

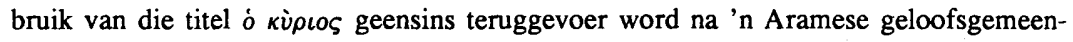
skap nie, omdat daar geen bewyse hiervoor in Joodse materiaal bestaan nie. Selfs as daar in die Arameessprekende kerk na Jesus verwys is as Mari (my Heer) of Maran (ons Heer), is die feit dat Mar nie gebruik is as titel vir God nie, 'n aanduiding daarvan

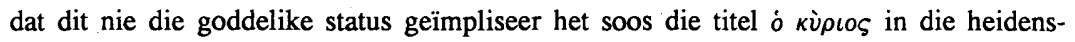
Hellenistiese gemeenskap nie. Diegene wat die naam van hulle Heer aanroep, word sy krag deelagtig. Bousset (1926:89) in sy kenmerkende poëtiese styl, beskryf hierdie unieke verskynsel soos volg:

Da erlebten sie die Wunder der Gemeinschaft, die Glut der Begeisterung eines gemeinsames Glaubens und einer gemeinsamen Hoffnung; da flammte der Geist auf, und umgab sie eine Welt voller Wunder; Propheten und Zungenredner, Visionäre und Ekstatiker beginnen zu reden, Psalmen, Hymnen und vom Geist eingegebene Lieder durchtönen den Raum, die Kräfte brüderlicher Mildstätigkeit werden in ungeahnter Weise wach; ein unerhört neues Leben durchspulst die Schar der Christen. Und über diesem ganzen Gewoge der Begeisterung thront der Herr Jesus als das Haupt seiner Gemeinde, mit seiner Kraft in einer den Atem raubenden Greisbarkeit in Gewissheit unmittelbar gegenwärtig.

\subsubsection{Die Christuskultus: Analogieë met ander kultusse in die Hellenistiese wêreld}

Analogieë vir die Christuskultus kan gevind word in die Romeinse keiserkultus waar 'n groot afstand tussen die heer en onderdaan, bestaan het. Hierdie keiserkultus se wortels lê in Egipte en dit moet ook teen die agtergrond van die misteriegodsdienste 
verstaan word. In Egipte byvoorbeeld het die opvatting geheers dat die farao die seun of inkarnasie was van ' $n$ god en is as sodanig vereer. Dié gedagte is deur die Persiese godsdiens verbreed. Die Persiese koning is gesien as in besit van die goddelike hemelse vuur wat aan hom oorwinning en heerskappy verskaf en verseker. Hierdie motiewe is deur Alexander die Grote en sy navolgers met Griekse elemente vermeng. In Egipte het die Ptolomeërs ' $n$ hele sisteem van regeerdersverering uitgebeeld. Hierdie regering neem 'n aanvang met Alexander as vereërde god en word afgesluit deur huwelike tussen broer en suster. Keiser Augus-tus het hierdie elemente van regeerdersverering benut en die keiserkultus ingestel waarvolgens die keiser as god vereer en as кìplos aangespreek is (Bousset 1913:91-101).

Crossan (1994:72-76) toon aan dat die Romeinse gebruik van keiserverering begin is deur Julius Caeser wat in 40 v C in Rome ' $n$ tempel opgerig het vir Venus Genetrix ('my ma, Venus'). Julius Caesar het daarop aanspraak gemaak dat hy die afstammeling is van 'n godin, naamlik Venus en 'n menslike vader Anchises. Caesar se opvolgers het dus op goddelike status aanspraak gemaak. In 9 v $\mathrm{C}$ word 'n vredesaltaar opgerig en aan die verering van die kì Lukas 2 word die verhaal van Jesus se geboorte vertel. Ons lees dat keiser ( $\kappa \dot{\nu} \rho\llcorner\circ$ ) Augustus die bevel uitgevaardig het dat 'n volkstelling gehou moes word. Die swanger vrou Maria en haar man Josef gaan na Betlehem, die stad van koning Dawid. Hiér word Jesus gebore - die Seun van God, gebore uit die maagd Maria. Waar Augustus dus die afstammeling is van 'n godin en ' $n$ menslike vader, word Jesus geteken as Seun van God en 'n menslike moeder (Crossan 1994:73). In Luk 2:11 word Jesus deur die engele aangespreek as $\sigma \omega \tau \grave{\jmath} \rho$ ŏ кúpıos Augustus staan die Redder, Christus die Here. Crossan (1994:75) stel hierdie teenstelling só:

But it still begs the real question, which is, then as now, where you find the divine manifest on this earth. Is it in Caesar, or is it in Jesus? Is it in imperial grandeur or peasant poverty? Is it in domination and subjugation of others from the top down, or is it in the empowerment and liberation of others from the bottom up? That's the real question.

Crossan (1994:72-76) se opmerking wek die vraag of die kontras tussen keiser Augustus en Jesus wat aan die begin van die Lukaanse narratief geskets word, konstant gehandhaaf word? (vgl ook paragraaf 7.3). 


\section{KRITIEK OP BOUSSET: HENGEL, RAWLINSON EN CROSSAN}

\subsection{Hengel: Die ontmoeting tussen Judaïsme en Hellenisme}

In sy boek Judentum und Hellenismus: Studien zu ihrer Begegnung unter besonderer Berücksichtigung Palästinas bis zur Mitte des 2 Jh.s v.Chr. (1973) toon Hengel oortuigend aan dat die skerp onderskeid wat daar deur Bousset en sy navolgers (waaronder ook Bultmann en Hahn) gemaak is tussen 'Judaïsme' en 'Hellenisme', 'Joodse apokaliptiek' en 'Hellenistiese mistiek', 'Joodse rabbynse tradisie' en 'Hellenistiese gnostiek', 'Palestynse' en 'Hellenistiese Judaïsme', 'Palestynse en Hellenistiese' gemeenskappe, nie meer haalbaar is nie. Hierdie onderskeid tussen twee tradisies neem glad nie in ag dat Palestina in Jesus se tyd alreeds vir 360 jaar onder Hellenistiese heerskappy en kulturele invloed was nie. Hengel se werk omskryf die ontmoeting tussen Judaisme en Hellenisme in die eerste helfte van hierdie 360 jaar.

In die eerste hoofstuk van Hengel se werk wys hy op die strategiese belangrikheid van Palestina wat die bron was van die twis tussen die Ptolomeërs en Seleukiede. Verder gaan hy voort om die betrokkenheid van die Jode in die Grieks-Hellenistiese oorloë te skets en verduidelik die ekonomiese toestand van Palestina onder die heerskappy van die Ptolomeërs. In hoofstuk twee word die kulturele invloed van Hellenisme in Palestina beskryf. Hengel wys op die invloed van die Griekse taal en die gebruik van Griekse noemname in Palestina asook op die invloed van die Griekse onderwys op Judaïsme. Hoofstuk drie verwys onder andere na die Griekse invloed op laat-Hebreeuse literatuur van die Ou-Testamentiese kanon, byvoorbeeld op die boek Prediker en op ander Judaïstiese geskrifte soos dié van Jesus Ben Sirag as reaksie op die Griekse libertinisme. Verder word die rol van die Hasidim as 'n Israelitiese pro-Hellenistiese party ten tye van die Hellenistiese hervorming bespreek, terwyl die Esseners as reaksie-groep teen hierdie hervorming ook aandag geniet. Ten slotte word in hoofstuk vier die Hellenistiese invloed op Israelitiese wysheidskonsepte en die identifisering van Jahwe met Hellenistiese voorstellings van God bespreek. Dié hoofstuk word afgesluit met 'n detail bespreking van die Hellenistiese hervormingspoging. In die lig van hierdie uitvoerige werk van Hengel kan die skerp onderskeid tussen die Palestynse Judaïsme en Hellenistiese heidendom nie meer gehandhaaf word nie (kyk ook Hurtado 1979:309).

\subsection{A E J Rawlinson: Die $\mu \alpha \dot{\rho} \rho \alpha \nu \alpha \alpha$-gebed as die Achilles-hiel in Bousset se argu- ment}

Volgens Rawlinson (1926:235) is die Aramese formula $\mu \alpha \dot{\alpha} \rho \alpha \nu \alpha \theta \alpha$ die Achilles-hiel van Bousset se hele argument. Bousset se tese dat die uitdrukking nie uit die Palestynse oergemeente stam nie, maar wel uit die Grieks- sowel as Arameessprekende gemeentes van Antiochië, Damaskus en Tarsus, is ernstig debatteerbaar. Hierdie Aramese gebeds- 
woord kan nie verklaar word sonder om die oudste tradisies in die Palestynse gemeente in ag te neem nie. Die formule $\mu \alpha \dot{\alpha} \rho \alpha \alpha \theta \alpha$ het volgens Rawlinson (1926:237) binne die liturgie van die vroeë Palestynse kerk ontstaan - dit is uitgespreek ten tye vàn die nagmaal (vir hierdie argument word Did 10:6 en I Kor 16:22 as bewyse aangevoer). Vanuit die genoemde voorbeelde kan die afleiding gemaak word dat die uitdrukking slegs as imperatief verstaan kan word by die nagmaal en die eskatologiese inrigting wat hierdie maal kenmerk (Conzelmann 1969:104; Hahn 1974:103).

Daar het dus alreeds in die sogenaamde Palestynse gemeente, om van Bousset se indeling gebruik te maak, 'n vorm van 'n Christuskultus bestaan waar 'n gesamentlike maaltyd gehou is. Hierdie maaltyd is gesien as 'n voonitskouing op die maaltyd wat in die volgende bedeling gevier sou word met Christus self as die gasheer. Sonder om hulle intensiewe apokaliptiese verwagting ter syde te stel, het die gemeente op grond van die opstandingsgebeure en met 'n sterk bewussyn van die naderende einde van hierdie bedeling, Christus as die komende Heer aangespreek.

\subsection{J D Crossan: Die 'Seun van die Mens'-kontroversie}

Wat die 'Seun van die Mens'-kontroversie betref, spreek Hurtado (1979:309) homself só uit: 'No single topic received as much attention in the journal literature of the past fifteen years as the quest concerning the origin of the Synoptic "Son of Man"-tradition'. Bousset se Kyrios Christos kan gesien word as die impuls van navorsing aangaande hierdie onderwerp. Sy siening dat die 'Seun van die Mens'-titel nie as selfbeskrywing deur Jesus gebruik is nie, is die dominante standpunt in die betrokke navorsingskringe. Die vraag wat dus aan die orde kom, is: het Jesus van Homself gepraat as die 'Seun van die Mens' of het Hy na 'n ander persoon verwys? Meer nog: moet die verwysings na die 'Seun van die Mens' teen 'n apokaliptiese agtergrond verstaan word?

Crossan (1992:238-255) kom met 'n nuwe insig vorendag en argumenteer dat die titel 'Seun van die Mens' as verwysend na die apokaliptiese regter nie by Jesus ontstaan het nie, en ook nie vanuit die gemeenskaplike mond van die vroeë Christelike gemeenskappe gekom het nie. Die verwysing 'Seun van die Mens' word nie aangetref in die apokaliptiese verwagtings van Paulus nie, ten spyte van toespelings op Dan 7:13, en dit kom ook nie voor in Did 16 of in die apokaliptiese visioene wat deur die Evangelie van Tomas teengestaan word nie. Tog kom dit as titel voor in die vroegste tradisies, soos gesien kan word in die Spreuke-evangelie Q, die Evangelie van die Hebreërs en die Evangelie van Markus. Die gevolgtrekking is dat die tema van die wederkoms van Jesus in die scenario van Daniël 7:13 teenwoordig is, sonder dat die benaming 'Seun van die Mens' as titel gebruik is. Dit is opvallend dat Paulus in 1 Tessalonisense 4:1318 die titel $\dot{o}$ kò $\rho$ loৎ gebruik in die apokaliptiese beskrywing van Jesus as die komende 
regter wat op die wolke sal verskyn (vgl ook Duling \& Perrin 1994:223). 1 Tessalonisense (ontstaan ongeveer $49 \mathrm{n} \mathrm{C}$ ) is ' $\mathrm{n}$ veel ouer geskrif as die Markusevangelie (ontstaan ongeveer $70 \mathrm{n}$ C) wat weer die benaming 'Seun van die mens' vir Jesus as apokaliptiese regter gebruik. Dit is baie duidelik dat die titel 'Seun van die Mens' nie die titel 'Kurios' voorafgegaan het soos Bousset (1913:76-8) beweer het nie. Verder blyk dit ook dat die titel 'Kurios' ook in apokaliptiese verband gebruik is en nie alleen as beskrywing vir die teenwoordige Heer van die gemeente nie (teen Bousset 1913:86). Hierdie stelling sluit aan by dié van Hahn (1974:189-193).

Hoe het die titel 'Seun van die Mens' dan ontstaan? Crossan (1992:255) stel voor dat daar in die vroeë tradisies ook tekste bestaan het waar Jesus self van die 'seun van die mens' in generiese sin gepraat het. Die teenwoordigheid van hierdie tekste het die oorgang bewerk van Jesus as die apokaliptiese regter (soos in Dan 7:13 beskryf) na Jesus as die 'Seun van die Mens' (ook in Dan 7:13). Bousset se voorstelling dat die benaming 'Seun van die Mens' ' $n$ voor-Christelike titel was met 'n duidelike betekenis en dat dit gegeld het as belydenis in die Palestynse oergemeente, lyk in die lig van nuwere navorsing al meer na historiese fiksie. Die vraag na die presiese vorm van Christologie in die vroeë kerk bly dus tot op hede nog onbeantwoord.

\section{DIE INVLOED VAN BOUSSET OP DIE WERK VAN BULTMANN EN SCHMITHALS}

\subsection{Rudolf Bultmann as leerling van Bousset}

Bultmann kan as een van Bousset se getrouste navolgers bestempel word. Hurtado (1979:307) spreek homself soos volg hieroor uit:

Though it is a major characteristic of modern NT Christology that Bousset's positions have dominated all subsequent research, it has to be said that, whatever the power of the book itself, part of the continued influence of Kyrios Christos is owed to Bultmann, who heartily endorsed Bousset's views on nearly all points and raised up many disciples.

As godsdienshistorikus het Bultmann gepoog om enersyds die godsdienstige oortuigings van die oer-Christendom binne tydshistoriese konteks as godsdienstige fenomeen te beskryf. Daarnaas het hy dit gedoen as teoloog om die eksistensie van die oer-Christelike gemeente toe te lig (Vorster 1987:145). Vir hierdie doel steun hy sterk op die tydskategorieë waarin Bousset die ontwikkeling van die vroeg-Christelike kerk verdeel. 
Bultmann (1956:90-110) sluit aan by Bousset se siening dat die apokaliptiese Joodse Christendom Jesus beskou het as 'Seun van die mens'. Hierdie oortuiging steun die standpunt dat Jesus Homself as apokaliptiese profeet gesien het. Die geskiedenis van Jesus lê in die verlengstuk van die Jodedom. Jesus se geskiedenis hoort tot die geskiedenis van die Jodedom en nie tot die geskiedenis van die Christendom nie. Hy was 'n Joodse profeet en sy verkondiging het die vooronderstelling vir die teologie van die oer-Christendom gevorm. Die verkondiging van Jesus was beheers deur die gedagte van die 'onmiddelik-voor-die-deur-staande-Godsheerskappy', en hiermee het $\mathrm{Hy}$ in historiese samehang gestaan met die Joodse eindverwagting. Volgens Bultmann (1956: 95) was Jesus vas oortuig dat die huidige wêreldtyd afgeloop was en in die lig van die nabyheid van die toekoms het die hede vir Hom die tyd van beslissing geword. As eindfiguur wat al hierdie dinge aan die gang sit, het Hy die 'Seun van die Mens' uit die hemel as regter en verlosser verwag (vgl ook Pelser 1989:818). Die vroegste Christene het hulle by die verwagting van Jesus aangesluit en Hom as die komende 'Seun van die Mens' verkondig en in die oortuiging geleef dat hulle reeds die eskatologiese tyd betree het. Bousset se siening dat die Hellenisties-heidense gemeente Jesus as die teenwoor-

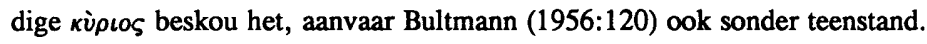

In die feesbundel vir Herman Gunkel lewer Bultmann in 1923 'n bydrae oor Der religionsgeschichtliche Hintergrund des Prologs zum Johannesevangelium (Bultmann [1923] 1967:10-35). Hy probeer deur 'n vergelyking tussen die proloog van Johannes, Israelitiese wysheidspekulasie en navorsing oor Manigese en Mandese spekulasie, aantoon dat daar 'n gnostiese verlossersmite ten grondslag van die proloog sou lê. Die doel van hierdie artikel is om die raaisel van die plek van die Johannesevangelie in die ontwikkeling van die oer-Christendom te probeer vasstel. Hierdie evangelie pas volgens Bultmann (1967:12-15) nie in die Palestynse Christendom soos verbeeld deur die Sinoptiese Evangelies nie, en ook nie in die Hellenistiese Christendom nie. Op grond van sy re-konstruksie van die geskiedenis van die verlossersmite en die geskiedenis van die Mandeërs wat hy as doopsekte terugvoer tot by Johannes die Doper, stel hy 'n ontwikkelingslyn vas in die geskiedenis van die oer-Christendom wat ouer is as die vorm van die Christendom wat in die Sinoptiese tradisie teruggevind kan word (vgl ook Vorster 1989:153). Hierdie vorm van Palestynse Joodse Christendom sou meer vatbaar wees vir Hellenisering as dié van die oergemeente in Jerusalem en sou 'n brug vorm tussen die Palestynse en Hellenistiese Christendom. S6 word die voorstelling van Bousset (1913) wat slegs onderskei tussen 'n Palestynse en Hellenistiese Christendom, gewysig. 


\subsection{Walter Schmithals: Die twee rigtings van die Hellenistiese Christendom}

Ook Schmithals (1994:86) gaan van die aanname uit dat daar 'n Israelities-Christelike gemeente in Jerusalem was wat hulle aangesluit het by die apokaliptiese verwagting van Jesus as 'Seun van die Mens'. Die verwagting van die Godheerskappy was gevestig op die Messiasbelydenis van Petrus (Hand 2:36) en die verhogingsteologie waarvolgens

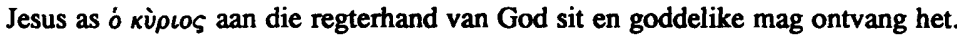

Hierdie Christologie ontwikkel in die Hellenistiese oorgang in twee duidelik onderskeibare rigtings (Schmithals 1994:87). Enersyds het die ontmoeting van hierdie Christologie met die Joodse gnostiek gelei tot 'n universeel gerigte tora-kritiese en sterk antropologies gerigte teologie met 'n preëksistensie Christologie (Schmithals 1994:89). Hiér oorheers ook 'n soteriologie wat die klem lê op die menswording van die Verlosser en die verlossing van die mens uit die mag van die sonde. Hierdie gemeente ontwikkel buite die sinagoge in 'n selfstandige gemeente met Damaskus as hoofsentrum. Die teologie van die Damaskusgemeente sou die kern vorm van Paulus se bekeringsteologie en die basis van die Johannese teologie (Schmithals 1994:89-91). Andersyds het die Christendom wat binne die Hellenistiese sinagoge ontwikkel het, 'n adopsiaanse Christologie ondersteun. Die kenmerk van hierdie Christelike ontwikkeling was 'n soteriologie georiënteer rondom die gebeure aan die kruis en die opstanding. 'n Vroeë sentrum van hierdie tipe Christelike ontwikkeling - die sogenaamde liberale sinagoge waarvan die deure vir die Godsvresende heidene geopen is - is Antiochië in Sirië. Vir die ontwikkeling van hierdie Christendom dien die Lukaanse korpus as bron (vgl ook Joubert 1991:145 wat die breuk met die Joodse sinagoge in $70 \mathrm{n} \mathrm{C}$ as die agtergrond vir die konfliksituasie in Handelinge skets). In die Antiocheense gemeente word Jesus ge-sien as die Messias, die nakomeling van Dawid wat verhoog word as Seun van God - Jesus word bely as 'Christos' én 'Kurios' (Schmithals 1994:93-106).

Schmithals (1994:84-106) steun dus wel op Bousset se indeling van die ontwikkeling van die Christelike kerk, maar sien dit nie as skerp onderskeibare fases nie. Daarbenewens stel hy homself ' $n$ skerper onderskeiding van die ontwikkelingsfases van die kerk(e) wat hulle ontstaan gehad het op nie-Palestynse bodem, voor.

\section{DIE ALTERNATIEF VAN HAHN MET BETREKKING TOT DIE BENA- MING 'KURIOS CHRISTOS'}

Aansluitend by Bultmann ([1923] 1967:10-35) verdeel Hahn (1974:10-2) die ontwikkeling van die Christelike kerk in 'n vroeë Jodedom (die Palestynse oergemeente), 'n Joods-Hellenistiese Christendom en 'n Hellenistiese Christendom. In sy werk Christologische Hoheitstiteln: Ihre Geschichte im fruhen Christentum (1974) stel hy homself ten doel om die Joods-Hellenistiese fase wat voor die verskyning van sy werk nog geen 
werklike aandag van navorsers geniet het nie, te ontgin. Waar Bousset (1913:76-104) in sy hantering van die benaming 'Kurios Christos' slegs 'Kurios' as titel hanteer het, met die veronderstelling dat 'Christos' slegs as eienaam funksioneer, stel Hahn dat die kombinasie van 'Kurios' en 'Christos' 'n spesifieke verwysing het. Hahn (1974:100103) is soos Rawlinson (1926) van mening dat die Palestynse oergemeente ook Jesus as kìpıs aangespreek het. Dit funksioneer as 'n beskrywing vir die hoogheid en volmag

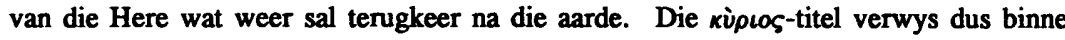
hierdie konteks na Jesus se eindtydelike funksie as Regter. Die verwagte Here van die gemeente is as 'ons Here' aangespreek deur middel van die Aramese gebedsaanroep $\mu \alpha \dot{\alpha} \alpha \boldsymbol{\nu} \alpha \theta \alpha$. Hierdie gebed was gebruik as vaste formule rondom die liturgie van die nagmaal en is dus met. 'n eskatologiese verwagting uitgespreek (Hahn 1974:100).

Onderskeidend van die Palestynse oergemeente is die xìplos-begrip op Hellenistiese bodem met die verhogingsmotief verbind (Hahn 1974:189). Aan die hand van die Septuagint se vertaling van Psalm 110, waar verwys word na die koning - die seun van Dawid of die Messias - wat op die troon aan die regterhand van God sal sit, is die beskrywing van Jesus as Here nou op Joods-Hellenistiese bodem verbind met die titel Xpırtòs, soos in Hand 2:36. Op dié wyse word kì Dit verwys na die Heerser, die verhoogde Jesus wat aan die regterhand van God sit en tydens die eindtyd sy vyande sal onderwerp (Hahn 1974:189-193). Die verhoogde Jesus sal nie slegs sy amp as koning eers aan die einde van die tyd voltrek nie, maar heers alreeds as koning, sittende aan die regterhand van God. Die gemeente kan hulle koning nie sien nie, nogtans bely hulle sy heerskappy. Op dié wyse word Jesus geskets as God wat sy gemeente regeer (die teenwoordige Here) en aan die einde van die tyd die nuwe bedeling sal laat aanbreek (die toekomstige Here). Waar Bousset (1913:1-33) Jesus op Palestynse bodem as toekomstige Here geskets het en op Hellenistiese bodem as die teenwoordige Here (Bousset 1913:76-104), verbind Hahn hierdie twee motiewe deur Jesus as verhoogde Heer op Joods-Hellenistiese bodem voor te stel.

\section{SAMEVATTING}

In die voorafgaande studie is aangetoon dat Bousset 'n duidelike onderskeid getref het tussen die apokaliptiese Israelitiese Christendom en die Hellenistiese Christendom. In die konteks van die Israelitiese Christendom is Jesus beskryf as die toekomstige 'Seun van die Mens', terwyl die Hellenistiese Christendom van Jesus as die teenwoordige 'Kurios' van die gemeente gepraat het. Volgens Bousset sou die Lukaanse korpus die volledige prentjie gee van die heidens-Hellenistiese Jesusbeeld. Die titel xìpı́s

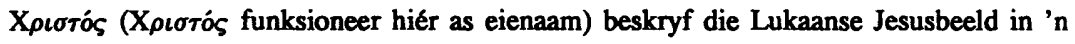
neutedop. Latere navorsing sou aantoon dat hierdie prentjie nie só eenvoudig is nie. 
Eerstens het Hengel (1973) beslissend gewys dat die skerp onderskeid tussen Palestynse Judaïsme en Hellenistiese heidendom nie meer haalbaar is nie. Hy lê hom daarop toe om die ontmoeting tussen Judaisme en Hellenisme te omskryf en wys daarop dat Palestina in Jesus se tyd alreeds 360 jaar onder Hellenistiese invloed was.

Rawlinson (1926:255) debatteer Bousset se stelling dat die titel kì die Hellenistiese heidens-Christelike gemeenskap as aanspreekvorm vir Jesus gebruik is (Bousset 1913:76-104). Volgens Rawlinson is die Aramese formule $\mu \alpha \dot{\alpha} \rho \alpha \alpha \theta \alpha$ (Kom, Here!) binne die liturgie van die vroeë Palestynse kerk uitgespreek ten tye van die viering van die nagmaal. Hierdie maaltyd is gesien as die vooruitskouing op die maaltyd wat in die volgende bedeling gevier sou word met Christus as gasheer.

Wat die 'Seun van die mens'-titel betref, stel Crossan (1992::238) dat die titel vir die apokaliptiese regter 'Seun van die Mens' nie by Jesus ontstaan het nie en ook nie vanuit die gemeenskaplike mond van die vroeē Christelike mond gekom het nie. Die teenwoordigheid van tekste waar Jesus van Homself as 'seun van die mens' in generiese sin gepraat het, het die oorgang bewerk van Jesus wat as apokaliptiese regter beskryf is (ook soms met die titel кù wederkoms van Jesus het dus in die scenario van Dan 7:13 voorgekom, sonder dat die benaming 'Seun van die Mens' gebruik is.

Bultmann (1956:90-110) aanvaar Bousset se stelling dat die Hellenisties-heidense gemeente Jesus as die teenwoordige кì skrywing van die Palestynse oergemeente. Hy rekonstrueer die geskiedenis van die gnostiese verlossersmite wat ten grondslag van die Johannesevangelie lê, sowel as die geskiedenis van die Mandeërs wat hy as doopsekte terugvoer na Johannes die Doper. Hiervolgens stel hy 'n ontwikkelingslyn vas in die geskiedenis van die Christendom wat ouer is as die vorm van die Christendom wat in die Sinoptiese Evangelies teruggevind kan word. Hierdie vorm van Palestynse Joodse Christendom sou meer vatbaar wees vir Hellenisering as die oergemeente in Jerusalem.

Schmithals (1994:86) verfyn weer op sy beurt Bousset se beskrywing van die Hellenisties-heidense gemeente. Hy onderskei tussen 'n Israelities-Christelike gemeente in Jerusalem, 'n gemeente in Damaskus wat afsonderlik van die sinagoge ontwikkel het en 'n Christelike ontwikkeling in hoofsaaklik Antiochië, 'n liberale sinagoge wat die deure vir Godvresende heidene geopen het. In die Antiocheense gemeente word Jesus gesien as die Messias, die nakomeling van Dawid wat verhoog word as Seun van God 'Christos' en 'Kurios'. Volgens Schmithals (1994:95) dien die Lukaanse korpus as bron vir hierdie tipe Christologie.

Die beeld van Jesus as verhoogde Heer is deur Hahn (1974) geïdentifiseer. Hahn is die eerste navorser wat erns gemaak het met die inhoudelike betekenis van die kombinasie 'Kurios Christos'. 'Hy argumenteer dat die titel kì oergemeente gebruik is, verwysende na Jesus se eindtydelike funksie as Regter. In 'n 
Israelities-Hellenistiese Christendom (wat deur Schmithals [1994:95] geïdentifiseer is as

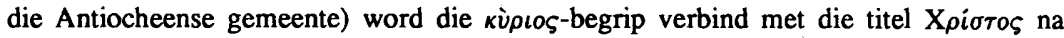
aanleiding van die Septuagint se vertaling van Psalm 110. Dit verwys na die Heerser, die verhoogde Jesus wat aan die regterhand van God sit en tydens die eindtyd sy vyande sal onderwerp. Op dié wyse word Jesus geskets as God wat sy gemeente regeer (die teenwoordige Here) en aan die einde van die tyd die nuwe bedeling sal laat aanbreek (die toekomstige Here).

Vanuit hierdie gegewens kan die gevolgtrekking gemaak word dat die Christologie wat in die Lukaanse korpus aangetref word, dié is van die Antiocheense gemeente. Hierdie gemeente het Jesus voorgestel as die verhoogde Here - 'Kurios' en 'Christos' - wat aan die regterhand van God sit. Die verhoogde Here regeer sy gemeente, en sal ook aan die einde van die tyd die nuwe bedeling laat aanbreek. Tog blyk dit dat die inhoudelike betekenis van die titel 'Kurios Christos' nog geen uitgemaakte saak is nie, veral in die lig van die onduidelikheid wat daar bestaan rondom die benaming 'Seun van die Mens'. Verder werk Hahn (1974) soos Bousset (1913) ook met 'n streng liniêre verstaan van die ontwikkeling van die Christelike kerk, opmerklik veral na die bydrae van Hengel (1973). Beide gee nie voldoende aandag aan die tradisies wat tussen Jesus en die Sinoptiese Evangelies ontstaan het nie. Hulle veronderstel 'n ononderbroke lyn tussen Jesus, die Sinoptiese Evangelies en die konteks van elke gemeenskap (die Sitz im Leben) waarbinne titels ontstaan het. Verder wys Kee (1984:191) daarop dat die geheel van die literêre korpus waarbinne 'n bepaalde titel funksioneer, nie voldoende deur navorsers in ag geneem is nie (vgl ook Boers 1970; Perrin 1971; Hurtado 1984 en Duling 1984).

\section{7. 'KURIOS CHRISTOS' IN DIE LUKAANSE KORPUS: DIE PAD VOREN- TOE?}

\subsection{Die probleem?}

Uit die voorafgaande studie blyk dit duidelik dat die oortuiging dat die 'Kurios Christos'-titel die Jesusbeeld van die Lukaanse korpus in 'n neutedop bevat, die navorser voor bepaalde probleme te staan bring. Nóg die agtergrond waarteen hierdie titel gefunksioneer het, nóg die referensie daarvan blyk 'n uitgemaakte saak te wees. Die vraag op die tafel is dus op watter wyse 'n ondersoek na die Jesusbeeld in die Lukaanse korpus aangepak moet word.

Word die kritiek op die histories-kritiese benadering van Bousset en Hahn in oënskou geneem, naamlik dat hulle selektief en atomisties te werk gegaan het, vra só 'n aanpak vir ' $n$ meer holistiese benadering. Dit sou onder andere beteken dat die intra- 
tekstuele, intertekstuele en ekstratekstuele verwysings in ag geneem moet word. Die intratekstuele konteks verwys na die onmiddelike konteks waarin 'n term, frase, sin of perikoop in 'n teks verskyn. Die intertekstuele konteks verwys na die teks se ver-: wantskap met ander tekste, dit wil sê die literêre verwysingsraamwerk-van die sender en implisiete ontvangers van 'n teks. Intertekstualiteit fokus dus op die verhouding tussen tekste en die interafhanklikheid van tekste. 'Hierdie 'verweefdheid' van tekste word soos volg deur Vorster (1989:59-60) omskryf:

All texts can be regarded as the rewriting of previous texts, and also as reactions to texts. The phenomenon 'text' becomes a network of traces, no longer a unitary object which is knowable, or a completed work with a centre and an edge which is recoverable by the skilled reader. Each sentence of this network creates intertextual patterns and points to intertextual connections.

Nuwere data wat nie aan Bousset bekend was nie, te wete die nuwe verkreë kennis as gevolg van die ontdekking van die Nag Hammadi-versameling asook die Qumran-geskrifte, behoort in ag geneem te word. Die ekstratekstuele konteks verwys na die kennis van ekonomiese, politieke, sosiale en godsdienstige omstandighede wat deur beide die sender en hoorders gedeel word en wat die sender dus as bekend by die hoorders veronderstel. In hierdie verband is dit ook noodsaaklik om daarop te wys dat daar in die Lukaanse korpus twee werklike sosiale wêrelde tegelyk opgeneem is: 'in die oorlewering, omvorming en herinterpretasie van vroeë tradisies (mondeling en skriftelik), is die Jesus-periode na die vroeë kerk-periode getranspareer' (Van Aarde 1994:12). Daar word dus van mense en dinge vertel vanuit 'n vroeë periode terwyl die latere periode waarin die vertelling finaal ontstaan en gekommunikeer het, in die vertelde wêrelde deursigtig is (vgl ook Duling \& Perrin 1994:27-29).

Dit is my oortuiging dat die sosiaal-wetenskaplike en narratologiese benaderings moontlikhede bied om albei hierdie wêrelde te verdiskonteer. Hierdie benaderings verteenwoordig ' $n$ meer holistiese aanslag op die vraag na die agtergrond en referensie van die 'Kurios Christos'-benaming in die Lukaanse korpus. Daar word vervolgens kortliks na hierdie benaderings gekyk en na die moontlikhede wat dit vir die hantering van die gestelde probleem bied.

\subsection{Die sosiaal-wetenskaplike benadering}

Die sosiaal-wetenskaplike kritiek bestudeer 'n teks (bv in die Nuwe Testament) as refleksie en respons op die sosiale en kulturele konteks waarbinne die teks ontstaan het. Die doel is om vas te stel wat die betekenis(se) van die teks op eksplisiete en implisiete 
vlak is. Daar word van die standpunt uitgegaan dat tekste betekenisvol kommunikeer as gevolg van die gemeenskaplike sosiale en kulturele sisteme waarbinne die skrywers en beoogde skrywers hulleself bevind (Malina 1983:1-10; Malina \& Neyrey 1988:xixvii; Malina 1993:6-9; Geyser 1995:3). As subdissipline van eksegese is die fokus primêr op die teks (in hierdie geval dié van die Lukaanse korpus). Soos alle interpretasie is dit egter ten nouste verbind aan ander dissiplines met 'n breër fokus, nie op die tekste nie, maar op die sosiale en kulturele sisteme in die algemeen soos dit bestudeer word deur onder andere historici, sosioloë, antropoloë en argeoloë (Malina 1993:12-20).

In hierdie verband onderskei Elliott (1994:60-70) tussen strategie (die doelbewuste ontwerp van die teks ter wille van effek) en situasie (die makro- en mikrovlakke van sosiale konteks). Daar word van die veronderstelling uitgegaan dat dit die korrelasie tussen strategie en situasie van 'n teks is wat die integrering van literêre en sosiaalwetenskaplike analises vereis en konstitueer. Terwyl die beskrywing van die strategie van 'n teks met behulp van literêre metodes aangepak word, vind die beskrywing van die situasie van die teks plaas met behulp van sosiaal-wetenskaplike eksegetiese metodes.

Daar is alreeds 'n aantal studies vanuit 'n literêre oogpunt op Lukas-Handelinge onderneem wat veral fokus op die rol van die intratekstuele outeur en leser (Joubert 1991:132). Ondersoeke na die sosiale en ekonomiese interaksie binne die Lukaanse gemeenskap en die kontrasterende sosiaal-religieuse funksies van die tempel en die huishouding is maar enkele van die belangrike navorsingstemas wat reeds in hierdie verband op Lukas-Handelinge onderneem is (vgl Elliott, in Neyrey 1991).

Malina \& Neyrey (1988:xi) identifiseer in hulle gesamentlike werk 'n Christologie 'van b6', 'van onder' en 'van die kant'. 'n Christologie van bo beskryf die dogmatiese aannames oor Jesus, soos dit ontwikkel het tydens die vierde- en vyfde-eeuse konsilies. Tydens hierdie konsilies het kerklui dogmas geformuleer wat Jesus as die Goddelike Woord van God beskryf, komende van die hemel en geinkarneer op aarde. Jesus is dus bely as 'ware God' en 'ware mens'. 'n Christologie 'van onder' verwys na kontemporêre beskrywings van Jesus, gebaseer op veral die Sinoptiese Evangelies. Die fokus hiér lê op die menslikheid van Jesus. Bousset, Bultmann en Hahn val in hierdie kategorie. Hierteenoor beoog Malina \& Neyrey (1988) eerder 'n Christologie 'van die kant'. Volgens hulle is vroeë Christelike groepe georganisseer in terme van sosiale verhoudings wat ook hulle ideologiese perspektiewe gedomineer het. 'n Christologie 'van die kant' sal dan beskryf hoe Jesus deur sy volgelinge en vyande 'geèvalueer' is. Malina \& Neyrey (1988:xi-xvii) foku' in hulle werk Calling Jesus names: The social value of labels in Matthew's Gospel op die onderskeie sosiale groepe in die eerste-eeuse 
Mediterreense wêreld, die waardes en belange wat hulle verteenwoordig en op watter wyse hierdie waardes tot uiting kom in benamings wat vir Jesus gebruik word in die Matteus-evangelie. Op dieselfde wyse sou dit sinvol wees om die benaming 'Kurios Christos' in die Lukaanse korpus te ondersoek.

Die sosiaal-wetenskaplike metode bied dus dié waardevolle insig dat daar erns gemaak sal moet word met die sosiale en kulturele konteks van die Lukaanse korpus asook die inhoudelike verwysing van die benaming 'Kurios Christos', gesien vanuit hierdie konteks.

\subsection{Die narratologiese benadering}

Vanuit 'n strategiese of literêre hoek gesien, funksioneer Lukas-Handelinge as 'n vertelling en dit behoort daarom geanaliseer te word met behulp van die narratologie, die wetenskap wat verteltekste ondersoek. Die Lukaanse korpus word as vertelling getipeer omdat die mees elementêre verskynsels wat die essensie van 'n vertelling uitmaak, in hierdie korpus aanwesig is, te wete 'n verhaal, verteller en tipe leser (Van Aarde 1991:4). 'n Vertelling kan derhalwe gedefinieer word as 'n 'diskoers waarin taal georganiseer is in terme van karakters wat in 'n bepaalde struktuur van tyd en ruimte beweeg, en 'n kronologiese sekwensie van episodes meebring wat in kousale verband met mekaar staan, dit wil sê, die plot' (Van Aarde 1991:5).

Tannehill (1985:69-85; 1986:1-9) toon aan dat die plot van Lukas-Handelinge opgebou is deur die wyse waarop die boodskap van die verlosssingwerk van Christus aan Israeliete en nie-Israeliete aangebied en aanvaar word. Die episodes in hierdie korpus

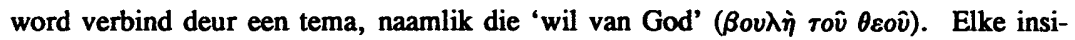
dent in die verhaal dra by tot die realisering van hierdie tema wat ook as die teologiese perspektief van die Lukaanse korpus beskryf kan word.

Aan die een kant is dit die wil van God dat Israel die boodskap van die verlossingswerk van God sal aanvaar. Die dissipels, getuies van die Here Jesus word dus na Israel gestuur wat hierdie getuienis verwerp. Op die wyse word die wil van God benadeel. Aan die ander kant is dit ook die wil van God dat die evangelie aan die nieIsraeliete verkondig word - hierdie sending is klaarblyklik suksesvol. Die Lukasevangelie stuur op Jerusalem af, die sentrum van die Joodse lewe. Jesus word gekruisig en dit blyk vervolgens dat die wil van God nie uitgevoer kan word nie. Hierop word daar gefokus op die nie-Israeliete - alle oë is op Rome gerig. Rome, die destydse hoofstad van die wêreld, is die simboliese eindpunt van die verhaal oor die geskiedenis van die heil van God (Tannehill 1985:83-85).

In 'n studie na die 'Kurios Christos' benaming vir Jesus, sou die navorser dus gaan vra na die wyse waarop die verteller by monde van die karakters hierdie titel aanwend ten einde die perspektief van die verteller uit te dra (met perspektief word hiér twee 
sake bedoel, naamlik die tegniese perspektief van waaruit die verteller die vertelde wêreld waarneem en vir die implisiete-geïdealiseerde leser aanbied en die ideologiese perspektief van waaruit die verteller die vertelde wêreld evalueer).

Tannehill (1985:69-85) toon aan dat daar literêre aanduidings in die teks van die Lukas-Handelinge korpus is wat daartoe bydrae om die perspektief van die verteller weer te gee. In die eerste plek word daar na gebeure in die narratief verwys wat buite die chronologiese orde van die verhaal val. Vooruitskouings van komende gebeure sowel as terugflitse na gebeure in die verlede word gegee. Tweedens word aandag gegee aan Ou-Testamentiese aanhalings en toespelings op Ou-Testamentiese gebeure. Sekere Ou-Testamentiese aanhalings ontsluit die Goddelike doel wat in die narratief ontvou. Verder word die doel van God gerealiseer deur menslike instrumente - mense wat deur God beveel word om sekere aspekte van die Goddelike plan uit te voer, soos Jesus, die twaalf apostels en Paulus. Jesus kondig byvoorbeeld aan die begin van sy sending in die sinagoge in Nasaret aan waarom Hy gesalf is (Luk 4:18-19). Hierdie uitspraak interpreteer die daaropvolgende gebeure van Jesus se prediking. Vierdens moet daar aandag geskenk word aan die menings van 'betroubare' karakters in die verhaal aangaande die doel van God en die betekenis van gebeure wat vertel word. Hierdie karakters dien as spreekbuise vir die outeur waarvolgens die leser gebeure in die verhaal behoort te interpreteer. Uitsprake van Jesus van Nasaret, Petrus, Stefanus en Paulus in Handelinge is belangrik vir die interpretasie van die verhaal.

Tannehill (1985:73) toon byvoorbeeld aan dat daar in die begin van die verhaal aanduidings is van wat later in die verhaal gaan plaasvind, deur te verwys na Simeon se reaksie op die baba Jesus (Luk 2:29-32). Hiér word vertel dat Jesus besondere betekenis vir beide Israel en die nie-Israeliete het. Wanneer hy Jesus sien, sien Simeon die verlossing ( $\sigma \omega \tau \dot{\eta} \rho \iota \nu)$ van God wat die 'lig' sal wees vir die nie-Israeliete en 'glorie' vir Israel. Hierdie tema van die universele openbaring van God se $\sigma \omega \tau$ ju haal in die aanhaling van Jesaja 40:3-5 in Lukas 3:4-6. Die enigste ander voorkoms van die term $\sigma \omega \tau$ in $\rho$ เov in Lukas-Handelinge is in Paulus se laaste uitspraak voor die Romeinse Israeliete aan die einde van Handelinge (28:28). Die voorkoms van die term $\sigma \omega \tau^{\prime} \rho t o \nu$ is 'n doelbewuste insluiting, sodat die einde van die Lukas-Handelinge verhaal terugverwys na die begin van die verhaal. Hierdie terugverwysing beklemtoon ook die verskil tussen die begin en die einde van die verhaal. Die finale toneel in Handelinge beklemtoon Paulus se uitspraak dat die Romeinse Israeliete en ander Israeliete blind en doof is, terwyl die nie-Israeliete wat hoor, die 'verlossing van God' sal ontvang.

Die verhaal van Israel in Lukas-Handelinge word as ' $n$ tragiese verhaal voorgestel. Tannehill (1985:75-83) gee ten minste ses aanduidings in Lukas-Handelinge waar die outeur die lesers doelbewus lei om die verhaal van Israel as tragies te beoordeel. Hierdie aanduidings sluit uitsprake van besorgdheid en hartseer deur sentrale karakters oor 
die lot van die volk Israel in. Een voorbeeld hiervan kom voor in vier tekste in die Lukasevangelie waar verwys word na Jerusalem, die verwerping van Jesus en die stad se komende verwoesting. Eerstens in Lukas 13:33-35, dan in Lukas 19:41-44, 21:2024 en 23:27-31. Die verwoesting van die stad Jerusalem word gesien as die Goddelike straf vir die verwerping van Jesus, maar die tọon van hierdie beskrywings wek eerder simpatie as wat dit veroordelend is. In Lukas 13:34-35 en 19:42-44 praat Jesus direk met die stad Jerusalem deurdat Hy die tweede persoonsvorm as aanspreekvorm gebruik. In Lukas 19:41-44 word Jesus geteken as iemand wat huil oor die lot van die stad. Volgens Tannehill (1985:75) is hierdie gebeurtenis opvallend omdat Lukas as redaktor oor die algemeen alle aanduidings van Jesus se emosies soos wat dit in Markus voorkom, verwyder het. Deurdat die outeur besondere gesag aan die karakter van Jesus toeken, word Jesus die gids vir lesers of hoorders se emosies. Wanneer Jesus oor Jerusalem huil, behoort ander ook oor die lot van Jerusalem te huil. In Lukas 21:23 en 23:28-31 word die lyding van die vroue en kinders van Jerusalem geskets. Jesus spreek die lydende 'dogters van Jerusalem' direk aan. Tragiese pathos word dus geskep deur die lyding van hulpelose kinders en vroue weer te gee. Alhoewel die verwoesting van Jerusalem deur Lukas gesien word as die gevolg van Israel se verwerping van Jesus, word die leser nogtans deur die karakter van Jesus gemotiveer om Israel simpatiek gesind te wees.

Die benaming 'Kurios Christos' by monde van die karakters dra ook daartoe by om die teologiese perspektief van die verteller uit te dra. . In Luk 2:11 word Jesus deur die

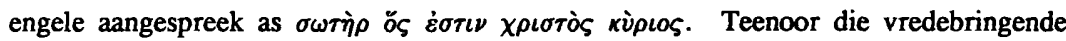
кúploৎ Augustus staan die Redder, Christus die Here (vgl paragraaf 2.2.4). Ook Petrus gebruik die titel 'Kurios Christos' vir Jesus in Hand 2:36 waar hy die 'Israelitiese manne en almal in Jerusalem' (Hand 2:14) aanspreek (vgl Schmithals 1980:40-41). Israel aanvaar egter nie die vredebringende boodskap van Christus, die Here nie en vervolgens word alle oë op Rome gerig - die setel van die kúpıos Augustus. Die verhaal van Lukas eindig in Hand 28 waar Paulus die Israeliete in Rome aanspreek. Die hoop is nog nie laat vaar dat Israel wel hierdie vredebringende boodskap sal aanvaar nie. Dit is ook nie toevallig dat Paulus hom juis in Rome bevind en dat Handelinge afgesluit word met die vermelding dat 'hy die koninkryk van God gepreek en onderrig gegee het aangaande die Here Jesus Christus', nie.

Hierdie enkele opmerkings laat die suggestie dat die vraag na die agtergrond en inhoudelike betekenis van die benaming 'Kurios Christos' onontbeerlik is vir die ondersoek na die opbou van die plot van Lukas-Handelinge. 


\section{SLOTSOM}

Die doel van hierdie artikel is nie om nou reeds antwoorde op die vraag na die agtergrond en inhoud van die benaming 'Kurios Christos', die Jesusbeeld in Lukas-Handelinge, te gee nie maar wel om an te toon watter wye omvang en problematiek aan die vraag verbonde is. Vanuit die ondersoek blyk dit duidelik dat daar rekening gehou sal moet word met die vraag na die inhoud van die titels 'Kurios' en 'Christos' onderskeidelik, sowel as die inhoud van die titels in kombinasie. Die situasie of agtergrond waarbinne hierdie titels gefunksioneer het, sal nog nagegaan moet word. Daar sal ook erns gemaak moet word met die Lukas-Handelinge as narratief, dit wil sè, die strategie van die teks.

Hoe problematies die vraag na die die Jesusbeeld in die Lukas-Handeling ook al mag wees, het hierdie studie beslissend aangetoon dat die vraag na die inhoud en ontwikkelings van Christologiese titels slegs gedoen kan word teen die agtergrond van die veranderde konteks van die Christelike kerk. Die omstandighede van die gemeenskappe wat die kerk gevorm het, is van die uiterste belang - 'n Christologie 'van die kant' blyk ' $n$ uitdaging te wees. Hierdie uitdaging aan die Nuwe-Testamentiese wetenskap kan nie geïgnoreer word nie!

\section{Literatuurverwysings}

Boers, H W 1970. Jesus and the Christian faith: New Testament christology since Bousset's Kyrios Christos. Journal of Biblical Literature 89, 450-456.

Borch, F H 1973. Forward and backward from Wilhelm Bousset's Kyrios Christos. Religion 3, 66-73.

Bousset, W [1913] 1926. Kyrios Christos: Geschichte des Christusglaubens von den Anfängen des Christentums bis Irenaeus. Göttingen: Vandenhoeck.

Bultmann, R 1956. Primitive Christianity and its contemporary setting. London: Thanes and Hudson.

- [1923] 1967. Der religionsgeschichtliche Hintergrund des Prologs zum Johannesevangelium, in Exegetica: Aufsätze zur Neuen Testaments, 10-35. Tübingen: Mohr.

Conzelmann, H 1969. Geschichte des Urchristentums. Göttingen: Vandenhoeck. Crossan J D 1992. The historical Jesus: The life of a Mediterranean Jewish peasant. San Francisco: Harper Collins.

1994. The infancy and youth of the Messiah, in Shanks, H (ed) 1994, The search for Jesus: Modern scholarship looks at the Gospels, 59-81. Washington, DC: Biblical Archeology Society. 
De Jonge, M 1988. Christology in context: The earliest Christian response to Jesus. Philadelphia: Westminister.

Duling, D C 1984. A response to Kee's christology and ecclesiology. Semeia 30, 193-199.

Duling, D C \& Perrin N 1994. The New Testament: Proclamation and parenesis, myth and history. Orlando: Harcourt Brace \& Company.

Elliott, J H 1994. What is social-scientific criticism? Minneapolis: Fortress.

Geyser, P A 1995. Die sosiaal wetenskaplike metode: Epistemologiese oorwegings. Ongepubliseerde klasaantekeninge, Departement Nuwe-Testamentiese Wetenskap (Afd A), Universiteit van Pretoria.

Hahn, F 1974. Christologische Hoheitstiteln: Ihre Geschichte im frühen Christentum. Göttingen: Vandenhoeck.

Hanson, R P C 1974. The Acts. Oxford: Clarendon Press.

Hengel, M 1973. Judentum und Hellenismus: Studien zu ihrer Begegnung unter besonderer Berücksichtigung Palastinas bis zur Mitte des 2 Jh.s v.Chr. London: SCM.

1986. Earliest Christianity. Containing Acts and the history of earliest Christianity, Property and riches in the Early Church. London: SCM.

Hurtado, L 1979. New Testament christology: A critique of Bousset's influence. Theological Studies 40/29, 306-317.

- 1984. New Testament christology: Retrospect and prospect. Semeia 30, 1527.

Joubert, S J 1991. Voort met die nuwe bedeling: Handelinge as paranetiese narratief binne 'n kosmopolitiese Christelike gemeenskap, in Roberts, J H (et al), Teologie in konteks, 131-156. Halfweghuis: Orion.

Kee, H C 1984. Christology and ecclesiology: Titles of Christ and models of community. Semeia 30, 171-192.

Ladd, G E 1993. A theology of the New Testament. Michigan: William B Eerdmans.

Malina, B J 1983. The New Testamemt world: Insights from cultural anthropology. London: SCM.

1993. Windows on the world of Jesus: Time travel to ancient Judea. Louisville: Westminister.

Malina, B J \& Neyrey, J H 1988. Calling Jesus names: The social value of labels in Matthew's Gospel. Sonoma: Polebridge.

Marshall, I H 1967. The development of christology in the early church. Tyndale Bulletin 18, 77-93. 
Neyrey, J H 1991. The social world of Luke-Acts: Models for interpretation. Peabody; Hendrickson.

O' Neill, J C 1961. The theology of Acts in its historical setting. London: SCM.

Pelser, G M M 1989. Rudolf Bultmann se ontmitologisering van die Nuwe-Testamentiese eskatologie. Hervormde Teologiese Studies 45/4, 815-842.

Perrin, N 1971. Reflections on the publication in English of Bousset's Kyrios Christos. Expository Times 82/11, 340-342.

Rawlinson, A E J 1926. The New Testament doctrine of Christ. London: Longmans Green.

Schmithals, W 1980. Das Evangelium nach Lukas. Zürich: Theologischer Verlag. (Zürcher Bibelkommentare.)

- 1994. Theologiegeschichte des Urchristentums: Eine problemgeschichtliche Darstellung. Stuttgart: Kohlhammer.

Tannehill, R C 1985. Israel in Luke-Acts: A tragic story. Journal of Biblical Literature 104/1, 69-85.

1986. The narrative unity of Luke-Acts: A literary interpretation. Philadelphia: Fortress.

Vorster, W S 1987. Rudolf Bultmann as historikus. Hervormde Teologiese Studies $43 / 1 \& 2,138-161$.

- 1989. The in/combatibility of methods and strategies in reading and interpreting the Old Testament. Old Testament Essays 2/3, 53-63.

Van Aarde, A G 1991. Eksegetiese metodologie: Narratologie. Ongepubliseerde studiehandleiding, Departement Nuwe-Testamentiese Wetenskap (Afd A), Universiteit van Pretoria.

1994. The names of Jesus in Matthew's story, in God-with-us: The dominant perspective in Matthew's story, and other essays. 44-71. Pretoria: University of Pretoria. (HTS Suppl 5.) 